\title{
Biochemical Characterization of Probiotics Available in Bangladesh
}

\author{
M. S. Hossain, M. A. A. Al-Bari, M. I. I. Wahed" \\ Department of Pharmacy, University of Rajshahi, Rajshahi-6205, Bangladesh
}

Received 10 October 2015, accepted in final revised form 17 December 2015

\begin{abstract}
The pervasive beneficial effects of probiotics are important for the maintenance of mammalian homeostasis. The probiotic products are consumed by people in their various forms available in Bangladesh. In this context, this study is taken into consideration to identify and characterize bacteria to confirm the scientific data needed for improvement in probiotic products as current therapies. Five probiotic samples were collected from pharmaceutical companies available in the retail pharmacy, Rajshahi. The probiotic samples are tested before expiration dates as marked on manufacturer packages. The culture media used were Czapek Dox ( $\mathrm{pH}$ 5.3), MRS and nutrient broth and agar for the investigation of lactic acid bacteria. The identified lactic acid bacteria (LAB) were lactobacillus acidophyllus (LAB 1), Lactobacillus bulgaricus (LAB 2), Lactococcus lactis (LAB 3) and Biffidobacterium biffidum (LAB 4) based on morphological characteristics, catalase activities, milk coagulation, carbohydrate fermentation profiles, resistance to antibiotics and other biochemical tests. The rejuvenation of probiotics particularly LAB from the probiotic samples can be used in other purposes such as biopreservation of lemon, orange juices with better tastes and fermented products like curds as well as hygienic qualities of other dairy products.
\end{abstract}

Keywords: Probiotic products; Lactic acid bacteria; Antibiotic susceptibility.

(C) 2016 JSR Publications. ISSN: 2070-0237 (Print); 2070-0245 (Online). All rights reserved. doi: http://dx.doi.org/10.3329/jsr.v8i1.25299

J. Sci. Res. 8 (1), 101-108 (2016)

\section{Introduction}

The mammal body is an excellent culture medium which provides nutrients and supports environment for the growth of a wide variety of microorganisms. The components of microbial species are known as the human microbiota. The peak bacterial population is found in the gut. Since the gut is essentially sterile at birth, a well-balanced microbial intestinal colonization is necessary for the development of appropriate immune responses in early postnatal life and to establish immune homeostasis later in life. Thus, probiotics in gut microbiota play an important role in the

\footnotetext{
*Corresponding author: wahed_mir@ru.ac.bd
} 
regulation of intestinal microbial homeostasis by maintaining gastrointestinal barrier functions such as prevention of pathogens from surface adhesion, interference with the ability of pathogens to colonize which in turn help to maintain the whole body homeostasis [1,2]. Any disturbances in the microbial colonization associate with an increased risk of numerous diseases such as gastrointestinal and autoimmune diseases. Probiotics have been classically defined as the live microorganisms actively enhance health benefit to the hosts [3]. Emerging published clinical evidences suggest that probiotics help to prevent various disease conditions such as gastrointestinal diseases like inflammatory bowel diseases, colorectal cancer, metabolic syndromes, Alzheimer's disease, autistic spectrum disorders, chronic fatigue syndrome, Parkinson's disease, autoimmune diseases like rheumatoid arthritis and multiple sclerosis, allergic diseases and, gynecological diseases (vulvo-vaginitis and mastitis) [3-8].

Recent studies on probiotic products showed that lactic acid bacteria are the main probiotic bacteria in the pharmaceutical preparations [3]. The interesting groups of microorganisms, lactic acid bacteria are characterized by their abilities to ferment carbohydrates into lactic acid, a weak acid conducive to the conservation and improvement of the organoleptic quality of food. Lactic acid bacteria comprise diverse groups of Gram-positive and non-spore-forming microorganisms. The growth of interest of lactic acid bacteria in the food industry lies mainly in their ability to convert some sugars into lactate and so, to acidify the surrounding environment. Fermentable carbohydrates are used as energy sources and are degraded to lactate (homofermentatives) or to lactate and additional products such as acetate, ethanol, carbon dioxide, formate, or succinate (heterofermentatives) [9]. The lactic acid bacteria produced as commercial starter cultures are pure cultures or a mix belonging to the genera Streptococcus, Lactobacillus, Enterococcus, Leuconostoc, Aerococcus Lactococcus, Streptococcus, Pediococcus and Bifidobacterium [10]. Thus, lactic acid bacteria can be widely used in food fermentation technology. The manufacturing of high-quality dairy and/or nondairy products requires close attention to characterization, differentiation, and maintenance of lactic acid bacteria as starter culture strains. The aim of the present study is to identify and characterize lactic acid bacteria in species level which can be used for several purposes such as biopreservation of fruit juices like lemon, orange juices with better qualities and extended shelf-lives or improved the tastes of fermented products like curds as well as hygienic qualities of other dairy products in addition to their therapies.

\section{Experimental}

\subsection{Sampling and isolation}

Five probiotic pharmaceutical preparations namely Probio (Square Pharma Ltd, Bangladesh), Prolacto (Drug International Ltd, Bangladesh), Protik Vitality (Kemiko Pharma Ltd, Bangladesh), Preotik (Meridian Medicare Ltd, India) and TS6 (Tensall 
Bio-Tech Company Ltd, Taiwan) were procured randomly from retailed pharmacy in Rajshahi division. The collected samples were stored in a refrigerator to maintain physical stability of the products. Total viable lactic acid bacteria counts in each sample were analyzed by spread plating the serially diluted samples onto the culture media, De Man, Rogosa and Sharpe (MRS) medium and nutrient broth and agar. After incubation at $15-37^{\circ} \mathrm{C}$ for $72 \mathrm{~h}$, colonies with clear zones were counted. Some of these colonies are selected and purified on nutrient agar medium and preserved the slants for a long time.

\subsection{Identification of bacterial strains}

For morphological characterization of probiotic bacteria, at first all colonies were used for microscopic observations such as colony morphologies including sporulation, margin elevation, surface pigmentation, opacity, growth patterns inside, at the bottom or on the surface of the medium and the rate of growth. The colony cultures were identified according to their physiological and biochemical characteristics $[11,12]$. The biochemical tests used were Gram staining; production of catalase; growth at different temperatures $\left(15^{\circ} \mathrm{C}, 25^{\circ} \mathrm{C}, 37^{\circ} \mathrm{C}\right.$ and $\left.45^{\circ} \mathrm{C}\right)$ for 3 days; growth resistance at $60^{\circ} \mathrm{C}$ for 30 min (Sherman test); growth at different $\mathrm{NaCl}$ concentrations and different $\mathrm{pHs}$ (2.56.5); fermentation profile of different sugars such as cellobiose, dextrin, fructose, glucose, galactose, lactose, mannose, sucrose, salicin or maltose in $1 \% \mathrm{w} / \mathrm{v}$, lactic acid production from $1 \% \mathrm{w} / \mathrm{v}$ lactose and motility $[13,14]$. For catalase test, in brief, growth from an overnight culture of the microbe was smeared on a microscope slide. A drop of $3 \%$ hydrogen peroxide $\left(\mathrm{H}_{2} \mathrm{O}_{2}\right)$ was added. If copious bubbles were observed, the microbe was positive for catalase otherwise negative. Colonies were characterized on nutrient and MRS agar and broth media. Strains with gram positive and catalase negative reactions were finally used for further identification [15].

\subsection{Testing for susceptibilities to antibiotics}

Bacterial antibiotic resistance was determined on solid MRS agar by the use of nine different antibiotic discs (Table 1). The results (average of 3 readings) were expressed as sensitive $(\mathrm{S})$ or resistant $(\mathrm{R})$ by following the standard disc diffusion method $[14,16]$. Standard antibiotics such as penicillin $\mathrm{G}(10 \mu \mathrm{g})$, amoxicillin $(30 \mu \mathrm{g})$, ceftriaxone (30 $\mu \mathrm{g})$, ceftazidime $(30 \mu \mathrm{g})$, kanamycin $(30 \mu \mathrm{g})$, tetracycline $(30 \mu \mathrm{g})$, streptomycin $(10$ $\mu \mathrm{g})$, erythromycin $(15 \mu \mathrm{g})$ and ciprofloxacin $(5 \mu \mathrm{g})$ were used for this study $[16,17]$.

\section{Results}

Here, we intended to identify mostly the probiotic bacteria which were potential for lactic acid production in MRS agar. The purification step of bacteria was performed by shifting Gram positive rods and cocci shaped bacteria to the plates of MRS agar media 
separately and repetitively. Lactic acid bacterial colonies were marked on the surface of MRS agar plates. In most of the cases more than one colony was recognized. With the help of a microscope, bacterial cultural and morphological characteristics were examined. A wide variety of microorganisms were distinguished, majority of them associated with the Gram positive, catalase-negative, non-motile, branched rods with singly in chains or clumps or non-filamentous rod-shaped microorganisms bends or with a large variety of branching although some are appeared in cocci shaped bacteria abled to produce lactic acid as main end-product of the fermentation of carbohydrates. After initial identification of lactic acid bacteria, the representative family, Lactobacillaceae and Bifidobacteriaceae were determined and the genus, Lactobacillus and Bifidobacterium were confirmed and segregated from other referred genus Lactococcus, Pediococcus, and some Leuconostoc [14,18,19]. Here, probiotic lactic acid bacteria were given priority to investigate for identification with rod and cocci shaped lactic acid bacteria only (other shaped sized bacteria were excluded). Finally, at least four strains of pure cultures (LAB 1-4) were selected for various biochemical and physiological characterizations and the results are given in Table 1 . These tests showed that all the four strains were Gram positive, non-spore rods and cocci (died at $60^{\circ} \mathrm{C}$ for $30 \mathrm{~min}$ ), motility negative and coagulated milk (Fig. 1). Moreover, there were no strains that exhibited any catalase activity. The optimum temperature for growth of most lactic acid bacteria (LAB 1-4) was between $30^{\circ} \mathrm{C}$ and $37^{\circ} \mathrm{C}$. Usually no growth was observed for the bacteria at temperatures below $20^{\circ} \mathrm{C}$ or above $46^{\circ} \mathrm{C}$. LAB1-4 could tolerate lower $\mathrm{pH}$ levels than many other bacteria. LAB 1 and 2 were able to grow and survive in fermented milks with $\mathrm{pH}$ values between 3.5 and 4.5 . LAB 4 tended to be less acid tolerant, surviving poorly in fermented milk at $\mathrm{pH}$ levels below 4.5. LAB 3 could survive in coagulated milk at $\mathrm{pH}$ values more than 5.5. The proper growth of LAB 1-4 were observed between 3.5-4.5\% NaCl. LAB 1 could survive at high level of $\mathrm{NaCl}$ concentration (6.5\%). It was observed that all the bacteria LAB 1-4 could not survive in presence of below $2.5 \%$ and above $6.5 \% \mathrm{NaCl}$ concentrations. All the strains were characterized further by sugar fermentation profiles and the results are appeared in Table 1. These results indicated that LAB 1 and 3 were strictly heterofermenters because both of them showed positive reactions for all the carbohydrates used (e.g. from cellobiose to maltose in Table 1). The results for LAB 2 indicated that the strain fermented fructose, glucose, galactose, lactose and mannose only but no other sugars. LAB 4 showed positive reactions with all the tested sugars except mannose, salicin. Table 1 showed the results obtained for antibiotic susceptibility of the eight different antibiotics tested. All strains were susceptible to ciprofloxacin, ceftriaxone, streptomycin, kanamycin and erythromycin. The strains LAB 1, 2 and 4 showed resistance to penicillin; LAB 3 was resistant to tetracycline and all the strains were resistant to ceftazidime (Table 1 ). 


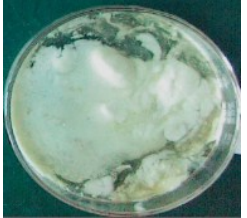

LAB 1

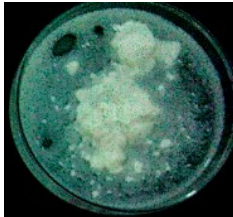

LAB 2

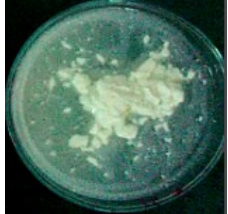

LAB 3

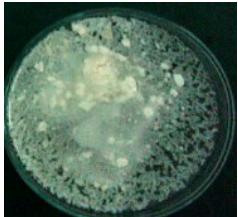

LAB 4

Fig. 1. Milk coagulation of probiotic bacteria.

Table1. Biochemical characteristics of probiotic bacteria.

\begin{tabular}{|c|c|c|c|c|c|}
\hline \multirow{2}{*}{\multicolumn{2}{|c|}{ Characteristics }} & \multicolumn{4}{|c|}{ Strain } \\
\hline & & LAB 1 & LAB 2 & LAB 3 & LAB 4 \\
\hline \multicolumn{2}{|l|}{ Colony morphology } & $\begin{array}{l}\text { White } \\
\text { round raised } \\
\text { translucent }\end{array}$ & $\begin{array}{l}\text { Circular, } \\
\text { irregular, } \\
\text { creamy } \\
\text { grey }\end{array}$ & $\begin{array}{l}\text { Circular } \\
\text { convex } \\
\text { grey, } \\
\text { smooth } \\
\text { and shiny }\end{array}$ & $\begin{array}{l}\text { White creamy } \\
\text { color, circular, } \\
\text { spatulate, } \\
\text { regular } \\
\text { contour }\end{array}$ \\
\hline \multicolumn{2}{|l|}{ Gram stain reaction } & + & + & + & + \\
\hline \multicolumn{2}{|l|}{ Catalase activity } & - & - & - & - \\
\hline \multicolumn{2}{|l|}{ Motility } & - & - & - & - \\
\hline \multicolumn{2}{|l|}{ Milk coagulation } & + & + & + & + \\
\hline \multirow{4}{*}{$\begin{array}{l}\text { Growth at } \\
\text { temperature }\left({ }^{\circ} \mathrm{C}\right)\end{array}$} & 15 & - & - & - & - \\
\hline & 25 & ++ & ++ & ++ & + \\
\hline & 37 & +++ & +++ & +++ & +++ \\
\hline & 45 & ++ & + & - & - \\
\hline \multirow[t]{5}{*}{ Growth at $\mathrm{pH}$} & 2.5 & - & - & - & - \\
\hline & 3.5 & ++ & ++ & - & +++ \\
\hline & 4.5 & +++ & +++ & + & +++ \\
\hline & 5.5 & + & + & +++ & $+/-$ \\
\hline & 6.5 & + & - & + & - \\
\hline \multirow{5}{*}{$\begin{array}{l}\text { Growth in a } \\
\text { medium with } \mathrm{NaCl} \\
(\%)\end{array}$} & 2.5 & - & - & - & - \\
\hline & 3.5 & + & + & + & + \\
\hline & 4.5 & + & + & + & + \\
\hline & 6.5 & + & - & - & - \\
\hline & 10 & - & - & - & - \\
\hline \multicolumn{2}{|c|}{$\begin{array}{l}\text { Heat resistance } 60^{\circ} \mathrm{C} \text { for } 30 \\
\text { min } \\
\text { Sugar fermentation profile }\end{array}$} & - & - & - & - \\
\hline \multicolumn{2}{|l|}{ Cellobiose } & + & - & + & + \\
\hline \multicolumn{2}{|l|}{ Dextrin } & + & - & + & + \\
\hline \multicolumn{2}{|l|}{ Fructose } & + & + & + & + \\
\hline
\end{tabular}




\begin{tabular}{|c|c|c|c|c|c|}
\hline \multirow[t]{2}{*}{ Characteristics } & & \multicolumn{4}{|c|}{ Strain } \\
\hline & & LAB 1 & LAB 2 & LAB 3 & LAB 4 \\
\hline Galactose & & + & + & + & + \\
\hline Lactose & & + & + & + & + \\
\hline Mannose & & + & + & + & - \\
\hline Sucrose & & + & - & + & + \\
\hline Salicin & & + & - & + & - \\
\hline Maltose & & + & - & + & + \\
\hline Production of lactic acid & & + & + & + & + \\
\hline Production of $\mathrm{H}_{2} \mathrm{O}_{2}$ & & + & + & + & + \\
\hline \multicolumn{6}{|c|}{ Resistance to antibiotics $(\mu \mathrm{g} / \mathrm{dl})$} \\
\hline Ciprofloxacin & 5 & $\mathrm{~S}$ & S & $\mathrm{S}$ & S \\
\hline Penicillin G & 10 & $\mathrm{R}$ & $\mathrm{R}$ & $\mathrm{S}$ & $\mathrm{R}$ \\
\hline Ceftriaxone & 30 & S & S & $\mathrm{S}$ & $\mathrm{S}$ \\
\hline Tetracycline & 30 & $\mathrm{~S}$ & $\mathrm{~S}$ & $\mathrm{R}$ & $\mathrm{S}$ \\
\hline Streptomycin & 10 & $\mathrm{~S}$ & S & $\mathrm{S}$ & $\mathrm{S}$ \\
\hline Ceftazidime & 30 & $\mathrm{R}$ & $\mathrm{R}$ & $\mathrm{R}$ & $\mathrm{R}$ \\
\hline Kanamycin & 30 & $\mathrm{~S}$ & S & $\mathrm{S}$ & $\mathrm{S}$ \\
\hline Erythromycin & 15 & $\mathrm{~S}$ & S & $\mathrm{S}$ & S \\
\hline Amoxicillin & 30 & $\mathrm{~S}$ & S & $\mathrm{S}$ & S \\
\hline
\end{tabular}

\section{Discussion}

Probiotics, the live microorganisms enhance actively in health benefit to the host. The beneficial effects of probiotic lactic acid bacteria are suggested to be due to a number of factors including regulation of intestinal microbial homeostasis, changes in the availability of nutrients and finally modulation of local and systemic immune responses [3]. Most of the probiotic microorganisms have a long history in biopreserving foods from spoilage microorganisms through inhibition of pathogenic bacteria and preservation of nutritive qualities of raw food material for an extended shelf life [20,21]. Therefore, it is important to identify and characterize probiotic lactic acid bacteria from commercially available that can be used for other purposes such as biopreservation of dairy and/or non-dairy food products. The results showed in Table 1 that all the four strains were non spore-forming rods and cocci, gram positive, nonmotile and non-catalase activity. So, these stains were fallen in the two families Lactobacillaceae (genus Lactobacillus) and Bifidobacteriaceae (genus Bifidobacterium). The results of growths at different $\mathrm{NaCl}$ concentrations suggested that all samples of probiotic lactic acid bacteria showed proper growth at $3.5-4.5 \%$ $\mathrm{NaCl}$ concentration except LAB 1 which could grow at higher concentration $(6.5 \%)$. Based on the sugar tests, LAB 1 and LAB 3 showed positive reactions for all the tested sugars. The results for $\mathrm{LAB} 4$ indicated that the strain gave negative reactions with only 
mannose and salicin while positive reactions were observed with all the other sugars. LAB 2 gave positive reactions with fructose, glucose, galactose, lactose and mannose only but no other sugars.

The results obtained from antibiotic susceptibilities of different antibiotics tested indicated that all strains were susceptible to most of the antibiotics including ciprofloxacin, ceftriaxone, streptomycin, kanamycin and erythromycin. However, all the strains showed resistance to antibiotics such as penicillin $G$ except LAB 3, ceftazidime (all strains) or tetracycline (LAB 3 only). As the wide spread antibiotic resistance might be dependent on excessive or indiscriminate use of antibiotics in this area of the world or due to chromosomal resistance, all the isolated lactic acid bacteria were resistance for different antibiotics such as ceftazidime, penicillin $\mathrm{G}$ or tetracycline. These results indicate mesophilic facultative heterofermentative lactobacillus acidophyllus (LAB 1) and Lactobacillus bulgaricus (LAB 2) and thermophilic obligate homo-fermentative Lactococcus lactis (LAB 3) and Biffidobacterium biffidum (LAB 4).

Traditional probiotic strains of lactic acid bacteria had a long history of safe use. There is considerable interest in extending the use in food preservation as well as immunomodulation by incorporating probiotic organisms from dairy foods to infant formulae, baby foods, fruit juice based [22] and cereal-based products and pharmaceuticals due to the ability of antimicrobial compound production by lactic acid bacteria [23,24]. Thus, understanding the interactions between the involved microorganisms, in different food systems, is very important in successful application of lactic acid bacteria to control other pathogenic microorganisms. This information is important in identification and selection of lactic acid bacteria for mix cultures as well as in the selection of stimulant bacteria in antimicrobial compound production using lactic acid bacteria.

\section{Conclusion}

This study provides a first time investigation of identification and characterization of lactic acid bacteria used in commercially probiotic products available in the local pharmacy market, Bangladesh. The identified probiotic lactic acid bacteria include lactobacillus acidophyllus (LAB 1), Lactobacillus bulgaricus (LAB 2), Lactococcus lactis (LAB 3) and Biffidobacterium biffidum (LAB 4) based on carbohydrate fermentation profiles, catalase activities and other biochemical tests. Although before isolation of these strains of lactic acid bacteria, there are different bacteria morphologies in the probiotic samples and the presence of traces pathogenic bacteria cannot be ruled out due to different sources, storage conditions or others. So, further investigation is required to identify these bacteria other than lactic acid bacteria in order to confirm the clarification of probiotic products by pharmaceutical companies.

\section{Acknowledgment}

This study was supported by 'Research Contract Program under Special Allocation for Science and Technology', Ministry of Science and Technology, as well as a research 
grant from the National Science and Technology (NST) fellowship funded by the Ministry of Science and Communication Technology, Government of the People's Republic of Bangladesh and Faculty of Science, University of Rajshahi, Bangladesh.

\section{References}

1. V. L. Miniello, A. Colasanto, F. Cristofori, L. Diaferio, L. Ficele, M. S. Lieggi, V. Santoiemma, and R. Francavilla R. Clin. Chim. Acta 451, 88 (2015). http://dx.doi.org/10.1016/j.cca.2015.01.022

2. J. F. García-Mazcorro, E. Garza-González, A. G. Marroquín-Cardona, and J. L. Tamayo. Gastroenterol. Hepatol. 38, 445 (2015).

3. J. M.Wells and A. Mercenier. Nat. Rev. Microbiol.6, 349 (2008). http://dx.doi.org/10.1038/nrmicro1840

4. F. Aragón, G. Perdigón, and A. de Moreno de LeBlanc, World J. Clin. Oncol. 5, 455 (2014). http://dx.doi.org/10.5306/wjco.v5.i3.455

5. G. C. Wall, G. A. Bryant, M. M. Bottenberg, E. D. Maki, and A. R. Miesner. World J. Gastroenterol. 20, 8796 (2014).

6. K. N. Lee and O. Y. Lee. World J. Gastroenterol. 20, 8886 (2014).

7. A. C. Ford, E. M. Quigley, B. E. Lacy, A. J. Lembo, Y. A. Saito, L. R. Schiller, E. E. Soffer, B. M. Spiegel, and P. Moayyedi, Am. J. Gastroenterol. 109, 1547 (2014). http://dx.doi.org/10.1038/ajg.2014.202

8. T. Danino, A. Prindle, G. A. Kwong, M. Skalak, H. Li, K. Allen, J. Hasty, and S. N. Bhatia, Sci. Transl. Med. 7, 289 ra84 (2015). http://dx.doi.org/10.1126/scitranslmed.aaa3519

9. O. Kandler and N. Weiss, Bergey's Manual of Systematic Applied Microbiology, 2 P.H.A. Sneath, N. Mair, M. E. Sharpe, J. G. Hott (Williams Wilkins, Baltimore Str., 1986) pp. 1209-1234.

10. F. Luquet and M. G. Corrieu, Lactic Acid Bacteria and Probiotics, 8C Edition (Tec Doc Lavoisier, Paris 307, 2005).

11. W. F. Harrigan and M. E. McCance, Laboratory Methods in Food and Dairy Microbiology, Rev. Edition (Academic Press, New York, 1976) pp. 33-200.

12. W. M. de Vos, M. Kleerebezem, and O. P. Kuipers, FEMS Microbiol. Reviews 29, 391 (2005). http://dx.doi.org/10.1016/j.fmrre.2005.05.001

13. L. Tserovska, S. Stefanova, and T. Yordanova, J. Culture Collect. 3, 48 (2002).

14. M. K. Islam, M. A. A. Al-Bari, A. Khan, M. K. Zahan, and M. A. Islam, Br. Microbiol. Res. J. 6, 24 (2015). http://dx.doi.org/10.9734/BMRJ/2015/14424

15. M. E. Sharpe, Identification Methods for Microbiologists (Academic Press, London, 1979).

16. K. Mourad and K. Nour-Eddine, Intl. J. Probiotics Prebiotics. 1, 27 (2006).

17. M. K. Islam, M. A. A. Al-Bari, M. S. Hasan, A. Khan, M. K. Zahan, and M. A. Islam. J. Adv. Biol. Biotechnol. 3, 1 (2015). http://dx.doi.org/10.9734/JABB/2015/15657

18. V. N. Mane and M. B. Gandhi, J. Environ. Res. Develop. 5, 384 (2011).

19. C. J. Gonzalez, J. P. Encinas, M. L. Gracia Lopez, and A. Otero, Food Microbiology. 17, 383 (2000). http://dx.doi.org/10.1006/fmic.1999.0330

20. C. C. Fuglsang, C. C. Johansen, S. S. Christgau, and J. Adler-Nissen, Trend Food Sci. Technol. 6, 390 (1995). http://dx.doi.org/10.1016/S0924-2244(00)89217-1

21. C. Pérez-Pérez, C. Regalado-González, C.A. Rodríguez-Rodríguez, J. R. BarbosaRodríguez, and F. Villaseñor-Ortega, Adv. Agri. Food Biotechnol. 37, 193 (2006).

22. M. K. Islam, M. S. Hasan, M. A. Mamun, M. K. Zahan, and M. A. A. Al-Bari, Adv. Pharmacol. Pharm. 3, 11 (2015).

23. T. Bansal and S. Garg, Current Pharmaceut. Biotechnol. 9, 267 (2008). http://dx.doi.org/10.2174/138920108785161587

24. V. Sreeja and J. B. Prajapati, Probiotics Antimicrobial Proteins 5, 81 (2013). http://dx.doi.org/10.1007/s12602-013-9126-2 